\title{
The Biology of Balanus balanoides. II. Algal Infection of the Shell.
}

\author{
By \\ M. W. Parke, Ph.D., \\ Marine Biological Station, Port Erin, I.O.M., \\ and \\ H. B. Moore, Ph.D., \\ Marine Biological Laboratory, Plymouth.
}

With 2 Figures in the Text.

In work on the biology of Balanus balanoides, use has been made of the method of differentiating the successive year groups by the colour of their shells. The present paper describes the method of doing this, and gives a brief account of the infective penetrative algæ which cause the colouration. The first author (M.W.P.) is responsible for the algological observations, and the second (H.B.M.) for the zoological observations.

\section{External Colour Changes.}

On an exposed shore, devoid of fucoid vegetation, the barnacles frequently form in summer a broad band which has the appearance of having been whitewashed on the rocks. The same zone in winter is much less conspicuous, being greenish brown in colour. Closer inspection of the barnacles shows that in summer they have a greenish brown apex, and a basal zone of varying width which is pure white (Fig. 1). In the case of the first year spat, the entire shell is white at this season. In winter the entire shell is of a greenish brown colour, although the shade varies according to the age of the animal. Figure 2 is a diagrammatic representation of the typical colour changes in the barnacle shells at Port Erin, based partly on field observations, and partly also on sections of the barnacles. Briefly, the new shell formed in the summer (Fig. 2, 1) gradually becomes coloured as the winter advances (Fig. 2, 2 and 3), practically the whole shell being coloured by the following spring (Fig. 2, 4 and 5). By early summer the old shell growth is sufficiently darkly pigmented to be sharply marked off from the new growth of white shell now making its appearance (Fig. 2,6). It will be noticed that the new area of white shell at this stage is disproportionately large, and the probable explanation of this is 
discussed in the section on the abrasion of the shell. The same sequence of colour changes described for the first year, is followed in the second and third seasons by the newly formed shells of those years, while the old shell of previous years continues to darken slightly.

This series of changes was verified on animals of known age from patches of rock which had been scraped prior to spatfall, and thereafter contained barnacles of known age only. It may therefore be concluded

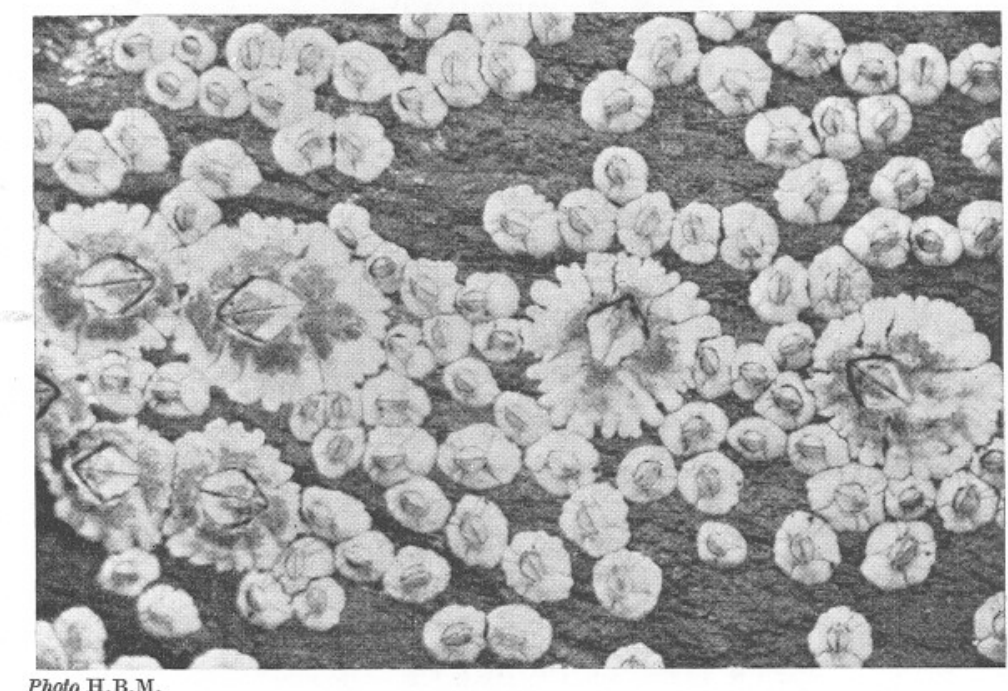

FIG. 1.-Barnacles of the 1932 and 1933 year groups, taken in Sept. 1933, showing algal infection of the upper zone of the older barnacles. $\times 2 \cdot 5$.

that, in this locality at least, colouration may be taken as a guide to the age of a barnacle up to two years old, and in some cases for a further year.

\section{The Cause of Colouration.}

Gruvel (1905) states that in some species of barnacles the shell is penetrated by algæ, of which he mentions the following: Hyella caspitosa (as H. caspitoda), Mastigocoleus testarum, Gomontia polyrhiza and perhaps Siphonocladus sp. Cotton (1912) records Plectonema terebrans "in the shells of Balanus " from Clare Island, but states that it is rare.

In the present work, part of the identification of the infecting algæ, and the examination of their distribution in the shells, was carried out on fresh material from four Manx localities as follows: outside Bradda Head (very exposed to wave action), Port Erin Bay (fairly exposed), Alfred Pier, Port St. Mary (sheltered), and Inner Pier, Port St. Mary (very sheltered). The material was obtained from surface scrapings of the shells, as well as 


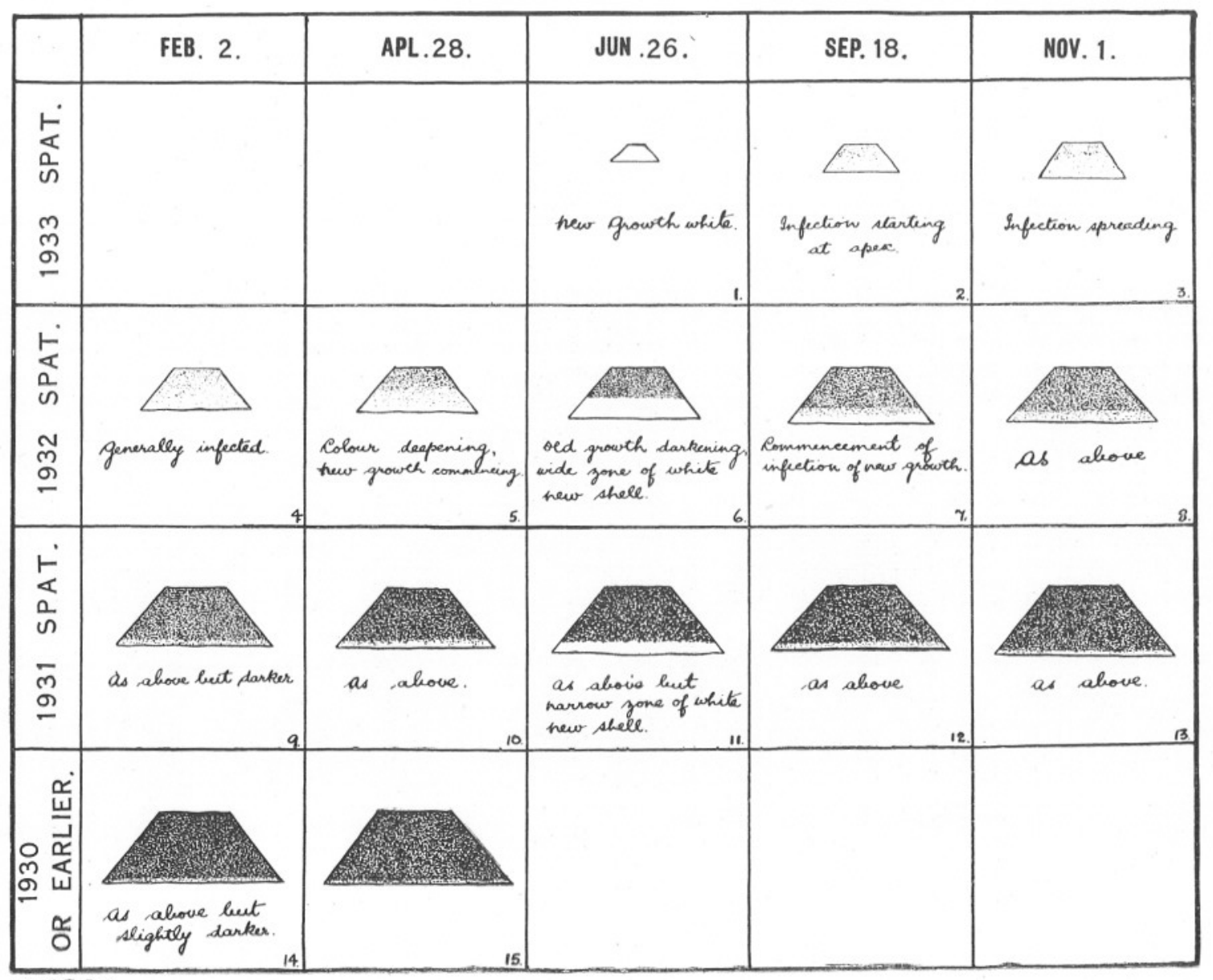

FIG. 2,-Schematic representation of seasonal colour changes in Balanus balanoides at Port Erin. 
by complete decalcification of the barnacles, both methods yielding complete plants which were more readily identifiable than those seen in section. In addition sections were prepared from barnacles from various tidal levels, chiefly in Port Erin Bay, but to some extent also from outside Bradda Head. Collections were made in 1933 on February 12th, April 28th, June 26th, September 18th and November 1st, and in all 233 barnacles were sectioned. The material was fixed in Bouin's fluid, decalcified in $5 \%$ nitric acid in $70 \%$ alcohol, cut at a thickness of $7 \mu$ and stained with Heidenhain's iron hæmatoxylin. The slides were originally prepared for examination of the condition of the gonads, but were found to be suitable also for showing the depth of algal penetration, and the approximate time of infection of the new shell zones.

The following is a list of all the species of algæ found by us penetrating the shells of the barnacles, together with notes on their distribution and fruiting.*

\section{CHLOROPHYCEÆ.}

Gomontia polyrhiza Born. et Flah. 'Figured, Newton, 1931, p. 96.

Perennial ; from H.W.O.S.T.† to L.W.O.N.T. ; generally distributed and very common; this species in particular is responsible for the green colouration of the shells; reproduction-sporangia present from December to March.

Ostreobium Queketti Born. et Flah. Figured, Newton 1931, p. 101.

Sporadic ; from H.W.O.S.T. to L.W.O.N.T. ; occasionally, outside Bradda Head; not in sufficient quantities to cause appreciable colouration.

\section{CYANOPHYCEÆ.}

Hyella caspitosa Born. et Flah. Figured, Newton 1931, p. 13.

Perennial; from H.W.O.S.T. to L.W.O.N.T.; very common and generally distributed ; chiefly responsible for the yellowish-brown colouration of the shells ; reproduction-gonidangia present in winter and spring.

Plectonema terebrans Born. et Flah. Figured, Tilden 1910, Pl. XI, Fig. 6.

Perennial ; from H.W.O.S.T. to L.W.O.N.T. ; common and generally distributed; chiefly responsible for the mauve-green colouration of the shells.

Mastigocoleus testarum Lagerh. Figured, Newton 1931, p. 41.

* In addition, the following species were found growing on the outsides of the shellsFucus spp. young plants, Pelvetia canaliculata Dene et Thur., Ralfsia verrucosa Aresch, forming brown patches on the shell surface, Enteromorpha spp. young plants, Laurencia hybrida Lenor., and the lichen Lichina pygmoea Ag.

$\dagger$ H.W.= high water, L.W.=low water, O.= ordinary, E.=equinoctial, S.T.=spring tide, N.T. $=$ neap tide, M.S.L. $=$ mean sea level. 
Sporadic; L.W.O.N.T. ; occasionally outside Bradda Head; not in sufficient quantities to colour the shell.

Microchate grisea Thur. Figured, Newton 1931, p. 43.

Perennial; H.W.O.S.T. to L.W.O.N.T.; frequent and generally distributed; this species is generally recorded as growing on the surface of the shell, but here it appears to penetrate into it; not present in sufficient quantities to colour the shell; reproduction-at all times throughout the year.

\section{Colonisation of the Shell.}

For the first three months after metamorphosis the shells of the young barnacles appear to be free from infection. This usually commences when the animals are from four to six months old, i.e. in SeptemberNovember, and appears first near the apex of the shell, which was the region first formed. An exception to this statement is the case, described later, of certain barnacles from their extreme upper tidal limit. In all the material examined, the first alga to infect the shell was Plectonema terebrans, which by November had penetrated to a depth of as much as 20-26 $\mu$. From December to February, when the animals are seven to nine months old, infection by Hyella caspitosa and Gomontia polyrhiza follows. The former was found in specimens of this age from all four localities, but Gomontia was chiefly in the material from outside Bradda.

By April the apical region of the barnacle shells is penetrated by algæ to a depth of $40-70 \mu$, although the basal region is still only slightly infected. From April to June the main shell growth takes place, the newly formed shell forming a sharply demarcated white zone below the infected upper region. The depth of new shell usually amounts to about half of the barnacle in these second-year animals, but there is considerable variation.

The course of events in the second year is very similar to that in the first year. Infection of the newly formed shell follows the course described above, while in the upper region the algæ which infected the shell the previous year continue to penetrate deeper, reaching by November a depth of $100-110 \mu$. The depth of the zone of shell added in the third year is less than that added in the previous year, but infection proceeds in the same way, and by the third winter the depth of penetration of the algæ in the oldest apical regions of the shell is $200-300 \mu$. Gruvel (1905) states that in some cases barnacles are penetrated to a depth of one to two millimetres, but this would be the whole thickness of the shell in all but the very thickest specimens found at Port Erin, where the greatest depth of penetration observed in Balanus balanoides was $0.3 \mathrm{~mm}$. 


\section{Correlation of the Presence of Barnacle-Penetrating Alge with Level and Exposure.}

With two exceptions there seems to be no correlation between the distribution of any of the species found and tidal level. The first exception is that of Ostreobium and Mastigocoleus, both of which were found only within a restricted tidal range, but this may perhaps have been due to the rarity of their occurrence. The second exception is the occurrence at the extreme top of their zone, of groups of barnacles with partially or completely uninfected shells. Such individuals are not found universally, but have been recorded in very local patches from outside Bradda, Port Erin Bay and elsewhere. In the most marked cases the shell was completely free from penetrating algæ, although there were small patches of an unidentified alga in crevices in the shell surface. In other examples, surface infection took the form of visible bands round successive areas of winter-formed shell. In barnacles collected at high water at Pooylvaaish, and which, from the number of these annual zones, appeared to be three or four years old, the apical region of the shell was beginning to be infected.

The time of commencement of infection does not seem to depend on tidal level. There is, however, a marked correlation between the abundance of some of the species and the degree of wave-exposure of the locality in which they occur. Gomontia is more abundant in the very exposed habitat outside Bradda than it is in the more sheltered ones, and both Ostreobium and Mastigocoleus were found only outside Bradda. On the other hand, Hyella, which is common in all localities, is most abundant in the two sheltered Port St. Mary localities, perhaps because other algæ are less abundant in the shells there, and competition is less as a result.

\section{Disintegration of the Shell.}

Darwin (1854, p. 55) describes certain species of Balanus, as well as other barnacles, in which the diameter of the orifice of the shell is normally increased to keep pace with growth, by a process of disintegration of the tips of the lateral plates. The instances cited by him are ones in which these plates either do not separate at all at their sutures as they grow, or else do not separate sufficiently. There is no mention of such a process taking place in the present species, nor would there seem to be any need for it, since the plates are fairly readily separable. But the evidence of the size of the white zone of new growth, relative to the infected previous year's growth, seems to show a disproportionately large growth in the second year, and one not in agreement with the growth rates as already determined for the species (Moore, 1934). A simple explanation lies in the fact that the observed growth rates refer to the final size of the shell, and 
take no account of any erosion that may have taken place; and that in fact a considerable amount of such erosion does take place, especially in the thin first-year shell. This would necessitate the renewal of some of the shell in order to maintain the same size, over and above the amount required in the process of increase in size, the two together producing the white zone of total growth seen at the end of the summer. Examination of sections shows that such is probably the case since the tips of the lateral plates are frequently infected through their entire thickness, and by such a quantity of algæ that very little shell remains. This must weaken the shell so considerably that it is hard to see how it could do other than crumble away at the edge. Examination of the larger barnacles on the shore also confirms the fact that the existing apical edge is not that of the first formed post-metamorphosis plates. For this reason the width of the infected area of the first year must not be used in a subsequent year as a measure of the size at the end of the first year.

\section{Relation between the Alge and the Barnacle.}

The infecting algæ are living in a part of the shell which apparently contains no animal tissue. There is thus no direct contact between the plant and the animal, and they cannot engage in direct transfer of salts or dissolved gases. On the other hand diffusion may perhaps take place through the shell to some extent, and also the alga will liberate metabolic products into, and withdraw others from the water immediately surrounding the barnacle. So it may be assumed that in addition to the protection afforded by the shell, the alga also benefits from the excretory products of the barnacle. The alga will in return benefit the barnacle by removing its waste products from the water, and will, in the daytime, contribute a certain amount of oxygen to the animal. The extent of the latter factor can be judged by watching a barnacle on a sunny day, when its surface is continuously giving off small bubbles of oxygen produced by photosynthesis of the algæ in the shell.

We wish to express our indebtedness to Dr. M. Knight for helpful criticism of this paper.

\section{REFERENCES.}

Bornet, M. M. 1887. Revision des Nostocacées Heterocystes. Ann. Sci. Nat., Sér. 7, T.V. Bot.

1888. Note sur deux nouveaux genres d'algues perforantes. Journ. de Botanique, T. II, p. 162.

1889. Sur quelques Plantes vivant dans le Test calcaire des Mollusques. Bull. Soc. Bot. France, T. XXXVI. 
Cotron, A. D. 1912. Clare Island Survey, Marine Algæ. Pt. 15. Proc. Roy. Irish. Acad., Vol. XXXI.

Darwin, C. 1854. A Monograph of the Sub-class Cirripedia. The Balanidæ, the Verrucidæ. London Ray Soc.

Gruvel, A. 1905. Monographie des Cirripèdes, ou Thécostracés. Paris. Moore, Hilary B. 1934. The Biology of Balanus balanoides. I. Growth and its relation to Size, Season and Tidal Level. Journ. Mar. Biol. Assoc., N.S., Vol. XIX, No. 2, p. 851.

Newton, L. 1931. A Handbook of the British Seaweeds. Brit. Mus. (Nat. Hist.), London.

Tildene, J. 1910. Minnesota Algæ. Vol. I. Rept. of the Survey. Bot. Ser. VIII, Minnesota. 